\title{
A CASE FOR TITLE INSURANCE IN THE SOUTH AFRICAN PROPERTY- REGISTRATION SYSTEM*
}

\author{
Maphuti Tuba \\ LLB LLM \\ Lecturer, Mercantile Law \\ University of South Africa (UNISA) \\ Edith Mbiriri \\ LLB LLM \\ Lecturer, Mercantile Law \\ University of South Africa (UNISA)
}

\section{SUMMARY}

Land and interests in land have traditionally been man's most basic forms of wealth. As a result, many elaborate legal systems have evolved to protect this wealth and the rights associated with it. This has led to the establishment of the most recognized land registration systems, namely the title registration system (known as the Torrens system) and the deeds registration system. Both of these systems provide owners of land and lenders with protection regarding property ownership and financial interests in land. South Africa has chosen to adopt the deeds registration system with some elements of the title registration system. This system is hailed as among the best in the world, simply because the validity of ownership and interests in land are the responsibilities of conveyancing practitioners and land registration officials. However, such protection is not fully guaranteed. This paper discusses the possibility of introducing title insurance - a form of indemnity insurance which insures a person against financial loss from defects in title to immovable property and from the invalidity or unenforceability of mortgage liens - to protect the financial interests of both land owners and lenders in the property.

\section{1}

\section{INTRODUCTION}

The purpose of this paper is to discuss the possibility of introducing title insurance in South Africa in order to provide compensation for losses

\footnotetext{
This is a revised version of a paper presented at the 8th International Conference on Legal, Security and Privacy Issues in IT Law 11-15 November 2013 Bangkok, Thailland. Financial assistance provided by CRIC and the Centre for Business Law of the College of Law (UNISA) is hereby acknowledged.
} 
caused to parties where there is a defect in the title registration process. It is evident that different land registration systems that are in place in many countries, including South Africa, do not provide absolute guarantees against all defects of title, nor do they address all disputes relating to land title. While some of these systems cover possible losses resulting from any defect or dispute in relation to land title, these measures are often inadequate. It therefore becomes necessary to propose a new method of ensuring that ownership to and interests in land are completely clear and free from any possible defects or adverse claims. In some countries, such as the United States of America (USA), private insurance, known as title insurance, is available to cover possible losses that are incurred by owners or lenders in relation to their title. This paper discusses the issue of whether or not title insurance is a viable option to supplement some of the shortfalls of the South African land registration system. Furthermore, the paper explores a few scenarios which provide support for the introduction of title insurance in South Africa.

\section{THE SOUTH AFRICAN LAND REGISTRATION SYSTEM AND ITS GUARANTEE OF TITLE}

The South African land registration system follows that of the classical Dutch-, negative registration system, albeit a modified negative registration system. ${ }^{1}$ The system is regarded, for the most part, as one of registration of deeds, in comparison with registration of title (commonly known as the Torrens system of land registration). ${ }^{2}$ In its operation, the negative deeds registration system requires instruments of title (and not the title itself) to be recorded and registered in the public deeds registry office. ${ }^{3}$ Such recording serves as evidence that a particular transaction has taken place, without any proof that the parties have a legal right to carry out the transaction. ${ }^{4} \mathrm{~A}$ document presented for recording is generally accepted at face value and is not subjected to detailed technical scrutiny by the registry office staff. ${ }^{5}$ Among the reasons advanced for the adoption of a negative land registration system in South Africa is the fact that registration is based on an abstract theory for passing of ownership. ${ }^{6}$ The abstract theory focuses on the

\footnotetext{
Silberberg Silberberg and Schoeman's The Law of Property (2006) 104. See Houtpoort Mining and Estate Sindicate Ltd $v$ Jacobs 1904 TS 105108 for the development of the South African registration system from Holland \& LAWSA XXVII Things par 376. Like the classical Torrens system, the registration of land in South Africa involved a registration before two commissioners of the Court of Justice (Formerly Politieke Raad). See Nel Jones: Conveyancing in South Africa (1992) 13.

2 Deeds Practice Manuals The Consolidated Practice Manuals of the Deeds Office of South Africa (2011) 1-2. For a discussion of the Torrens land registration system, see Cameron The Torrens System: Its Simplicity, Serviceability and Success (1915).

3 Barry, Hunter and Muhsen "Scalable Land Tenure Records Systems" 20081 Technika Chronika Science Journal 1113

4 McEwen "The Principle of Material Publicity of the Land Register" 20123 Advanced Research in Scientific Area 523529.

6 Msomi "The Abstract System and S 100" 4 March 2012 GhostDigest. See also Bhuqa "Causal or Abstract?" 28 March 2010 GhostDigest.
}

5 Ibid. 
importance of the mutual intention for the transfer of property. ${ }^{7}$ It considers ownership to have passed if there was delivery accompanied by the parties' intention to transfer and acquire ownership. ${ }^{8}$ In terms of the abstract theory, it does not matter whether or not the preceding agreement was valid. ${ }^{9}$ As the intention cannot be established based on the instruments submitted for registration, such registration may be incomplete and defeasible if the correct status of the parties' mind is established. ${ }^{10}$

The other reason for characterizing it as negative is that registration does not guarantee or reflect a true picture of the state of affairs. ${ }^{11}$ For example, a spouse who is married to the sole owner of the property becomes co-owner by virtue of the marriage regime, notwithstanding the incorrect state of affairs in the registered documents. ${ }^{12}$ The system, however, has some elements of guaranteeing indefeasible title to land in terms of which some of the warranties are tacitly provided. The following discussion of the relevant provisions of the Deeds Registries Act ${ }^{13}$ (the DRA) highlights the extent to which the land registration system attempts (successfully or not) to provide for a guarantee of title and compensation in the case of loss arising from defects in title.

The procedures for the registration and transfer of titles in South Africa are primarily regulated in terms of the DRA. This piece of legislation, according to Nel, "is a codification of the practice; though not a complete codification". ${ }^{14}$ In terms of section 16 of the DRA, ownership of land is conveyed by a deed of transfer duly executed and attested by the registrar. ${ }^{15}$ The DRA has the element of a "government-based lawyer" examining deeds, similar to the one in the classical Torrens system. ${ }^{16}$ Before a transfer can be executed, all deeds and the supporting documents submitted for registration must be examined for legality and registrability. ${ }^{17}$ If such deeds

7 Hosten, Edwards, Nathan and Bosman Introduction to South African Law and Legal Theory (1983) 338-342.

8 See Commissioner of Customs \& Excise v Randles, Brothers \& Hudson Ltd 1941 AD 369 398-399; Trust Bank van Afrika Bpk v Western Bank Bpk NNO 1978 (4) SA 281 (A) 301 H302A; and Concor Construction (Cape) (Pty) Ltd v Santambank Ltd 1993 (3) SA 930 (A) 933A-933C. These decisions have also settled the law that the abstract theory now applies to immovable property.

9 Schutte "The Characteristics of an Abstract System for the Transfer of Property in South African Law as Distinguished from a Causal System" 201215 Potchefstroom Electronic LJ 120121.

10 See Bester NO v Schmidt Bou Ontwikkelings CC 2013 (1) SA 125 (SCA) discussed in par 4 below.

11 Deeds Practice Manuals The Consolidated Practice Manuals 1-2.

12 Ibid. Other cases involve passing of ownership by expropriation, which is yet to be noted in the deeds registry.

1347 of 1947.

14 Nel Conveyancing in South Africa 13.

15 In terms of the proviso to this section, transfer to a state or local authority may be made by endorsement.

16 Janczyk "Economic Analysis of the Land Title Systems for Transferring Real Property" 1977 6 The Journal of Legal Studies 213 223. The authors draws a comparison between the examination of the validity of transfer of title by private lawyers under the classical deeds system and the examination by goverment-based lawyers under the Torrens system.

17 S 3 (1)(b) read with reg 45(7) of the DRA. 
or documents are not permitted by the DRA or any other law, the examiner (an official of the deeds office) must reject the transfer if he or she can raise a valid objection for such rejection. ${ }^{18}$ The examination is essentially to ensure the legality of the transaction and to enforce the priority principle (in terms of which recording guarantees priority in law to the first recorded transaction), while successive and double transfers are avoided. A modification of negativity is also evident in section 3(1)(y). This section imposes a duty on the registrar to keep such registers for the purposes of "maintaining an efficient system of regulation calculated to afford security and title". ${ }^{19}$ The section is an attempt by the South African land registration system to achieve the granting of original title. However, the DRA also reflects some elements of negativity. In terms of section 100, a formal defect in connection with any registration of a deed does not invalidate any act of registration unless "a substantial injustice has been done". Firstly, the section seems to acknowledge that, although the register must afford security, the system cannot ignore possibilities of formal defects. Secondly, it acknowledges that such formal defects may cause substantial injustices. This section is substantiated by other provisions in the DRA which attempt to address formal defects and other defects that may cause these injustices. These provisions include section 4(1)(b), which gives the registrar the power to rectify an error in the description of the parties' names, property or conditions in the deed. ${ }^{20}$ The DRA further provides for rectification (i.e. reversal of transfer) where, as a result of registration, the same property is transferred to two owners ${ }^{21}$ or incorrect properties are registered in the name of different parties. ${ }^{22}$ Furthermore, instruments registered may be cancelled by an order of the court if the reason for such defect cannot be justified under the DRA. ${ }^{23}$ These provisions constitute a clear indication that registration under the South African registration system is incomplete and no full title can be guaranteed. Section 3(1)(y) also provides for the keeping of registers, whether by means of a computer or any other manner.

Several of the countries with the most advanced land registration systems, such as Canada, New Zealand, England and Australia, have implemented an electronic land registration system. ${ }^{24}$ The advantages of this move to electronic registration include a faster and more efficient method of conveyancing, an increase in the accuracy of costs, and the reduction of

Ibid.

9 Authors' own emphasis added.

20 For a discussion of this section, see Tuba "Section 4(1)(b) of the Deeds Registries Act 47 of 1937 as a Remedy for the Mistaken Transfer of Land Bester NNO v Schmidt Bou Ontwikkelings CC [2012] ZASCA 125 (21 September 2012)" 201334 Obiter 565.

21 S 39 of DRA.

22 The latter procedure is not specifically regulated in terms of the DRA, but the first author, having worked as a deeds examiner at the Pretoria Deeds Office, acknowledges a long practice of making applications to rectify erroneous transfers under these circumstances.

$23 \mathrm{~S} 13$ of the DRA.

24 See Low "Opportunities for Fraud in an Electronic Land Registration System: Fact or Fiction" 200613 eLaw Journal 225. See also Mostert "Tenure Security Reform and Electronic Registration: Exploring Insights from English Law" 201114 Potchefstroom Electronic LJ 85; and Peterson "Two Faces: Demystifying the Mortgage Electronic Registration System's Land Title Theory" 201153 William \& Mary LR 111. 
costs. ${ }^{25}$ Based on the developments in these countries, discussions are underway in South Africa to introduce an electronic deeds registration system which will allow for the lodging of deeds and registration, without having to set foot in the registry office. ${ }^{26}$ This move, as discussed below, is criticized for compromising the integrity of the registration system and subjecting the interests of parties to defects and consequential financial loss. ${ }^{27}$ Fraudulent signatures, lack of authenticity of documents and parties are some of the challenges that may be experienced as a result of the move to electronic deeds registration. ${ }^{28}$

Despite its regulation of defects, the DRA provides only a limited guarantee of title and provisions for compensation where an act of registration causes damages to a prejudiced party. ${ }^{29}$ Although a registrar is required to be diligent, the Government or registrar may generally not be held liable for damages sustained as a result of defects in registration in terms of section 99. The impact of this section is that the Government will only be liable in cases where all the requirements for the claiming of damages are proved before the court, unless the Government or registrar of a particular deeds office admits responsibility and the matter is settled out of court. $^{30}$ The section is also a tool to encourage the officials of the deed office to exercise care and diligence in their duties. ${ }^{31}$ The Government may be liable if the act of the registrar or the deeds official was mala fide or if he or she did not exercise reasonable care and diligence, which resulted in loss or damage. ${ }^{32}$ The DRA also imposes personal liability in addition to the State compensation in section $99 .{ }^{33}$ The State compensation provisions, however, only provide for "title risk", which relates to defects of title arising from the registration and recording of documents at the deeds registry office. It is only defects in the registration of title that are covered. It is therefore limited in terms of "off-title risks", such as attorney's fees, or any expenses incurred during court proceedings or adverse claims against property. The section does not provide, for instance, for personal liability of the conveyancer where his or her conduct causes damage to the transacting parties. ${ }^{34}$ In section 15 , instruments which are lodged for purposes of registration can be prepared

\footnotetext{
Low 200613 eLaw Journal 226.

See Anon "EDRs Bill" 10 March 2011 GhostDigest.

Whittle "Comments on EDRs Bill" 8 April 2010 GhostDigest; and see also Mostert 201114 Potchefstroom Electronic LJ 102.

28 Low 200613 eLaw Journal 225; Mostert 2011 Portchefstroom Elelctronic LJ 85; and Perterson 2011 William \& Mary LR 111.

29 Nel Conveyancing in South Africa 17.

30 S 99 of DRA.

West "Deeds Examiner Beware" 22 August 2013 GhostDigest.

32 S 99 of DRA.

33 See Flaws Compensation for Loss under the Torrens System - Extending State Compensation with Private Insurance Paper presented at the Conference on Taking Torrens into the 21st Century University of Auckland Zealand (2003) for a discussion of the State compensation provided by the Torrens system through the compensation fund.

34 See West "Role Players" 2 February 2012 GhostDigest for a detailed discussion of the conveyancer's responsibilities.
} 
only by the conveyancer. ${ }^{35}$ This person is responsible for proving the accuracy of certain limited facts mentioned in the deeds or documents which he or she is required to certify. ${ }^{36}$ The section does not specifically provide for liability. It is implicit in the section that any defects that may be caused by the conveyancer's act or omission may render him or her liable for any loss suffered. However, this section, like section 99 , relates to liability in relation to title risks. It does not address some of the losses that may be suffered as a result of conduct outside the registration system. The question is whether or not title insurance can be utilized to indemnify the affected parties against these losses. Before attempting to answer this question, title insurance will be discussed.

\section{TITLE INSURANCE}

\section{Definition of title insurance}

The owners of land have the right to possession of such land and to enjoy the interests that come with it. However, this enjoyment may be affected if the correct information is not obtained in relation to the title when such ownership is acquired. In other countries, title insurance was introduced specifically for title insurance companies to obtain such relevant information. Title insurance traces its origins back to the USA property market, wherein ownership of land is determined by a title search generally conducted by private lawyers or title insurance companies. ${ }^{37}$ The buyer would obtain the insurance, firstly for the company to conduct a title search, and secondly to cover him or herself against any risk in the event that there was something wrong with the title. ${ }^{38}$ It was thus largely motivated by its coverage of risks relating to inherent shortcomings of the title-search methods. ${ }^{39}$

Title insurance refers to an agreement whereby the insurer agrees to indemnify the insured (holder of a right in immovable property) for loss caused by reason of existing defects, liens and encumbrances affecting the title. ${ }^{40}$ The indemnification also includes the insurer's duty to search the title for defects and to defend the title if it becomes necessary. ${ }^{41}$ If a dispute

35 See s 102 of DRA. A conveyancer is a person who is practising as such and who is admitted as an attorney and has written a special conveyancing examination, as required by the Law Society of South Africa.

36 S 15A of DRA, read with regulation 44. The facts include the capacity of all persons who signed the documents, the correctness of the names, the authority of the parties to represent each other, etc.

37 Title insurance was introduced in the United States as early as 1853 by the Law and Property Assurance Society in Pennsylvania. See Jaffee "Monoline Restrictions, with Applications to Mortgage Insurance and Title Insurance" 200628 Review of Industrial Organization 8 92; and French and Lusk Law of Real Estate Business (1984) 107. Kurtz and Hovenkamp Cases and materials on American Property Law (1993) 107.

39 lbid.

40 Haymond "Title Insurance Risks of which the Public Records Gives no Notice" 19282 Southern California LR 422 422; and see also Sandler v New Jersey Realty Title Ins. Co., 36 N.J. 529*529 471, 478-479 (1962).

41 Arrunada "A Transaction-Cost View of Title Insurance and its Role in Different Legal Systems” 200227 The Geneva Papers of Risk and Insurance 582582. 
arises, the insurer will defend the insured and if the defence is unsuccessful, then the insured will be indemnified accordingly. Title insurance protects an owner or lender against unknown defects in the title. ${ }^{42}$ It also provides protection against the risks inherent to the uncertainty of land titles by insuring against potential losses from other people who might have an interest in the same title, which has the possibility of clouding or invalidating the title.

\section{Types of title insurance}

Title insurance is available to both owners of land and lenders of immovable property, with the most common policies being an owner's policy and a lender's policy. ${ }^{43}$ It is trite to say that these two groups have separate interests in a title, which require different forms of protection. An owner's policy is used to protect the interests of ownership and possession, and it is also available to prospective buyers of land. The lender's policy ${ }^{44}$ protects the insured's collateral interest, which the lender has in the insured property. ${ }^{45}$ Since they insure different interests, there are clear differences between an owner's policy and a lender's policy. Firstly, a lender's policy can be assigned to another lender, while an owner's policy is not capable of assignment. ${ }^{46}$ Secondly, a lender's policy will protect the insured against the title which proves to be "unmarketable". ${ }^{47}$ This simply refers to a title to immovable property which a reasonable buyer would not be willing to accept. ${ }^{48}$ However, it does not mean that the property is free from defects or encumbrances. Thirdly, a lender's policy usually extends the cover to defects that could be discovered upon inspection. Such defects are usually excluded from an owner's policy. The lender's policy does not have exceptions for claims that can be detected from the physical inspection of the property, whereas an owner's policy may contain such exclusions. ${ }^{49}$ In addition, an owner's policy covers the insured for the amount paid for the property, while the holder of a lender's policy is protected for the loan amount, and this amount decreases on repayment of the loan. ${ }^{50}$ Although the two are different, as shown above, they operate in the same way, as they purport to protect the insured against any threat posed to a title to immovable property.

42 Rejda Principles of Risk Management and Insurance (2011) 267.

43 Burke The Law of Title Insurance (2000) 2-4.

44 It is sometimes referred to as the Mortgagee Policy.

45 O'Connor "Double Indemnity-title Insurance and the Torrens System" 20033 Queensland University of Technology Law \& Justice Journal 141142.

46 Burke The Law of Title Insurance 4.

47 Morgan "Title Insurance: Its Relevance to Lenders" in Jackson and Wilde (eds) Contemporary Property Law (1999) 171; and see also Deleon v WSIS Inc. 728 So. 2d 1046 (La Cr. App 1999) 1049.

48 Morgan in Jackson and Wilde (eds) Contemporary Property Law 171.

49 Cortes Mastering Real Estate Principle (1996) 169.

50 Ibid. 


\section{Differences between title insurance and other property insurance}

Title insurance falls into the category of indemnity insurance, similar to most types of property insurance. The insurer only becomes liable if the insured has suffered an actual loss. Just because there is a defective title, the insured does not have the automatic right to claim in terms of the contract. Actual loss has to be shown and proved. ${ }^{51}$ There are significant differences between title insurance and other types of property insurance, which makes it very unique. While other property-insurance contracts provide cover for future losses, title insurance insures against loss resulting from past events that existed prior to the insurance taking effect. ${ }^{52}$ It operates in a retrospective manner in order to protect the insured against losses that are caused by undiscovered defects or encumbrances in the title that existed at the time of contracting. ${ }^{53}$ Morgan contends that this assertion is partially correct, because the insurance offers protection for future losses caused by defects existing at the time of the contract. ${ }^{54}$ It is submitted that this contention is correct, since the loss is experienced in the future, even though the circumstances causing it existed from the past events and were not known at the time.

Unlike other property-insurance contracts, where the focus is on the assumption and spreading of risk, title insurance is aimed at loss avoidance ${ }^{55}$ As a result, the insurer will have to investigate and examine all the documents and records that are related to the title in question. The title search is also necessitated by the fact that property may have a long history of transactions between the people who might have interests in it, and some of those interests may still be in existence. ${ }^{56}$ Therefore, if such defects are discovered, they can be cured. Alternatively, they may be put under the exclusion clause. The title insurer is in the unique position of being able to eliminate claims. The insurer is in a position to issue a policy after conducting a title search, which is aimed at reducing the number of claims. ${ }^{57}$ The policy is based on the assumption that no loss will occur. ${ }^{58}$ This is necessitated by the fact that the insurer would have done a thorough search before issuing the policy.

Unlike other insurance contracts, where the premium is payable on a regular basis, title insurance requires the payment of only one premium when the policy is issued: which is an average of half of one per cent of the property value. ${ }^{59}$ The reason for a single premium is that the premium is not

51 Johnson "The Nature of Title Insurance" 19963 Journal of Risk \& Insurance 393397.

52 Chicago Title Insurance Company $v$ Washington State Office of the Insurance Commissioner No. 87215-5 (Wash. Aug. 1, 2013).

53 Ibid.

54 Morgan in Jackson and Wilde (eds) Contemporary Property Law 169.

55 Quiner "Title Insurance and the Title insurance Industry" 197322 Drake LR 711714.

56 Burke The Law of Title Insurance 4.

57 Burke The Law of Title Insurance 2-16.

58 Rejda Principles of Risk Management and Insurance 267.

59 Morgan in Jackson and Wilde (eds) Contemporary Property Law 170. 
based on the expectation of a future event. It is based on the insured event that occurred in the past, and not discovered by the search for the title record. It therefore has a low-risk capacity. ${ }^{60}$ The search will reveal if there are any defects already existing in the title. Moreover, a title-insurance policy does not have any specified term or expiration date. It remains in force for as long as there are potential losses that the insured may suffer in relation to his or her title to land. ${ }^{61}$ This means that for as long as there is a possibility of loss that the insured may incur, the contract will remain in force. The policy does not cease to protect the insured when he sells the property, and the cover extends to the beneficiaries of his estate. ${ }^{62}$ The only requirement is that the title defect occurred before the date of the policy, regardless of when it is discovered.

\section{Risks covered under a title-insurance policy}

The risks that are covered by the title insurers vary from one insurer to the other or from specific provisions of a particular insurance policy. However, most policies generally cover the same risks. Firstly, title insurance covers against a defective title. ${ }^{63}$ The defective title may be a result of liens against the property which were not discovered through the title search. The protection extends to the undiscoverable defects that would have been in existence at the time of contracting. ${ }^{64}$ The cover also encompasses known title defects such as the servitude of right of way (known as easements) and any condition that restricts the use of the property. ${ }^{65}$ Moreover, it also covers hidden defects such as insolvency events, void instruments or incorrectly executed documents. ${ }^{66}$ Secondly, the insured in a title-insurance contract is protected against the risk of an unmarketable title. The title-insurance company may buy the property when a buyer refuses to buy it because of the non-marketability of the title. ${ }^{67}$ Although this protection is not afforded by all title insurers, many are in favour of the inclusion of this risk in their policies. Thirdly, title insurance companies cover errors in the title examination due to negligence and fraud committed by the person responsible for the title search on behalf of the title company. ${ }^{68}$ This makes sense, since human errors have the potential of affecting the title and if they are excluded, the insured will be punished for someone not having done their job properly and diligently. The fourth risk covered by title insurance relates to those defects that are ordinarily discovered through an examination of title by the title-insurance company. ${ }^{69}$ Some title insurers do a partial search of the records for various reasons, including, among others,

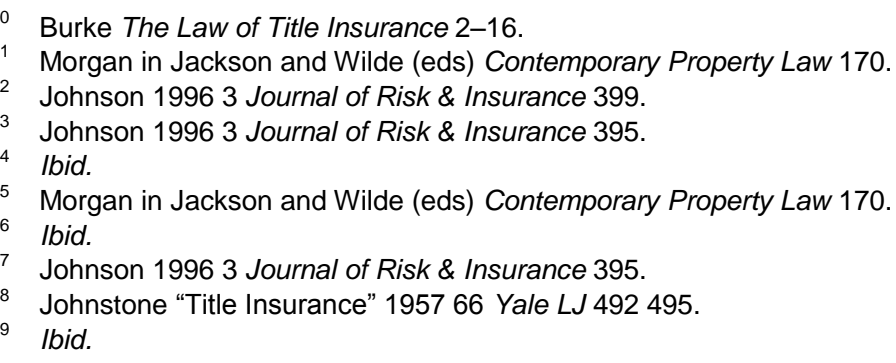


the expensive nature of the title search. Title insurance may also cover "off title risks" such as the attorney's fees, costs granted against the insured by the court, and all expenses incurred during court proceedings relating to any claim of interest or dispute relating to property. ${ }^{70}$ This may cover, for instance, "any claim or litigation against any insured occurring prior to, or pending as of the inception date of the policy" ${ }^{71}$ Similar to other risks covered under the insurance, such claim must have been initiated in the past or still be continuing, even if the financial loss may only be incurred in future.

\section{Risks excluded by title insurance}

Just like any other insurance contract, title insurance contracts also contain a list of the risks that are generally excluded. Firstly, governmental regulations that restrict the use and enjoyment of property are excluded from the risks that are covered by the policy. ${ }^{72}$ These include zoning, building and fire regulations. Their exclusion is an indication that ownership of land is ultimately subject to control and regulation by the Government. ${ }^{73}$ The exclusion of these regulations is probably because the title insurer cannot protect the insured against the Government, since all ownership is subject to Government control. Another exclusion closely related to the first is the exclusion of transfer in terms of forced sale or expropriation. The other exclusion relates to defects that are apparent on physical inspection and a survey of the title. These types of defects are generally excluded from the owner's policies, although they may be included in the lender's policies. ${ }^{74}$ Furthermore, defects that result subsequent to the date of the title-insurance contract are excluded. ${ }^{75}$ These defects are probably excluded on the grounds that title insurance generally protects the insured against loss that is caused by past defects. Acts of the insured are also excluded from the cover. $^{76}$ These acts are probably excluded because after contracting, the insured will be in control of the title and in a position to know or be part of other third parties' rights that may affect his title. In addition, any defects which are known by the insured when he entered into the contract are also excluded. ${ }^{77}$ Thus, if the insured is responsible for the circumstances creating the defect, such as fraud, the insurer may not be held liable. Title insurance only protects against loss caused due to a defective title to immovable properties. Movable properties of the insured are not covered under title insurance, even if the property is affixed to the immovable property. Lastly,

70 Ghezeli v First American Title Insurance Company cases no DO61070 (24 July 2013) Unreported.

71 Lexington Insurance Company v Integrity Land Title Co case no: 12-1599 (US court of Appeal $8^{\text {th }}$ Circuit) (31 July 2013).

72 Rooney "Title Insurance: A Primer for Attorneys" 197914 Real Property, Probate and Trust Journal 608613.

73 Ibid.

74 Johnstone 195766 Yale LJ 496.

75 Ibid.

76 Rooney 197914 Real Property, Probate and Trust Journal 614.

77 Ibid. 
certain hidden defects such as the mechanic's liens ${ }^{78}$ are excluded. ${ }^{79}$ However, the liens may be covered in the lender's lien, provided that upon a physical inspection of the property there was no sign of recent construction. ${ }^{80}$

\section{Comparison between title insurance and state compensation}

The introduction of title insurance in certain jurisdictions is often refuted because of the existence of State compensation systems and the provision by title registration legislations for rectification of errors or defects of title. In those countries where both types of assurance exist, arguments are often raised that they may constitute double indemnity for the same loss. ${ }^{81}$ It suffices to say that the issue of double indemnity (which is not in the province of this discussion) is curable by the principle of subrogation. ${ }^{82}$ In countries where state compensation does not exist, it was held in the New Zealand case of Registrar-General of Land $v$ Marshall that "insurance in some form, would need to be created". "In addition, natural justice, as correctly argued, "demands that compensation should be given in such cases where mistakes of clerks or officials in transferring title may result in overlapping rights and causing loss to a holder". ${ }^{84}$

These debates are answerable by briefly comparing the two types of insurance. As the relevant provisions are discussed below, what is known as State guarantee is provided in both the deeds system as well as the Torrens system. ${ }^{85}$ The Torrens system guarantees indefeasibility of title and provides State-indemnity funds against loss caused by any defect in the title. However, it is only limited to "title risks", that is, risks that emanate from the recording and registration of title. ${ }^{86}$ For instance, it does not guarantee the validity or the priority of interests in the registered land until such interests are registered. ${ }^{87}$ Likewise, the existing State compensation schemes also do not cover pre- and post-acquisition risks which occur before registration of the property. ${ }^{88}$ As a result, any "off-title risk" is not covered by the State compensation scheme. Another limitation of State compensation is that

78 Mechanic liens are liens created when an owner of property fails to pay for work relating to the construction of the premises, putting that payment as a charge on the property even when it is sold, and conferring some rights on the person who did the construction. Johnstone 195766 Yale LJ 497.

80 Ibid.

81 O'Connor 20033 Queensland University of Technology Law \& Justice Journal 8.

82 Flaws paper presented at the Conference on Taking Torrens into the 21st Century 13-14. Flaws argues that because this claim is akin to a claim for damages, it is unlikely that an insured would seek compensation from the State first, rather than making a claim against the title insurer.

83 Registrar-General of Land v Marshall [1995] 2 NZLR 189194.

84 Cameron The Torrens System 100.

85 O'Connor 20033 Queensland University of Technology Law \& Justice Journal 10.

86 Flaws paper presented at the Conference on Taking Torrens into the 21st Century 7.

87 Flaws paper presented at the Conference on Taking Torrens into the 21st Century 8.

88 O'Connor 20033 Queensland University of Technology Law \& Justice Journal 10. 
indemnification is a statutory right. Unless loss is brought within the precise statutory formula, no compensation may be payable. ${ }^{89}$ For instance, before any compensation can be paid, the state of mind of a responsible State official or the level of care and diligence required must be proved before the State can be held responsible. ${ }^{90}$ State compensation also requires a causal nexus between the mistake (that is, of the registry official) and the loss, thus elevating the requirement to the high status of a claim for damages in common law. ${ }^{91}$ Owing to these stringent requirements, State compensation is often referred to as "a compensation of last resort". ${ }^{92}$ Although State compensation is sometimes referred to in insurance terms, the claimant is not lodging an insurance claim to cover loss. In actual fact, the claimant is bringing an action against the State in the form of a statutory damage.

Title insurance, on the other hand, covers significantly more risks. It does not only cover defects in a title that occurred during the registration process. It also covers title-searching risks, as well as pre-acquisition risks, which are unlikely to attract compensation under the State compensation scheme. ${ }^{93}$ The procedure for claiming under this type of insurance is generally not stringent. The important requirements to prove are that the claimants hold a valid policy, the loss that is covered by the policy has occurred, and that the circumstance(s) giving rise to such loss are not excluded. ${ }^{94}$ There is no need to establish a causal nexus between the particular act and the loss. The simplicity of the claim thus makes title insurance a compensation of first resort in comparison to State compensation. ${ }^{95}$ The question is therefore whether or not title insurance is a viable option for the protection of both the owner and the lender under the South Africa land registration system.

\section{CIRCUMSTANCES IN SUPPORT OF TITLE INSURANCE IN SOUTH AFRICA}

On 08 December 2007, the electronic server at the Pretoria deeds office experienced an unexpected shut-down as a result of unstable power supply. ${ }^{96}$ This resulted in the loss of thousands of copies of title deeds and registered documents between 25 August and 8 December $2007 .{ }^{97}$ In order to address the consequences of this loss for those with interests in these documents, conveyancers, financial institutions, local authorities, provincial governments and the general public who were in possession of paper copies of title deeds and documents were requested to re-submit them to the

\footnotetext{
Flaws paper presented at the Conference on Taking Torrens into the 21st Century 5.

See the discussion of $s 99$ of DRA in par 5 below.

Flaws paper presented at the Conference on Taking Torrens into the 21 st Century 7.

Flaws paper presented at the Conference on Taking Torrens into the 21st Century 11.

O'Connor 20033 Queensland University of Technology Law \& Justice Journal 10.

Flaws paper presented at the Conference on Taking Torrens into the 21st Century 11. Ibid.

96 Property24 (24 February 2008) http://www.property24.com/articles/pta-deeds-office-losesdeeds (accessed 2013-09-12).

97 Registrar's Circular 1 of 2008 (Pretoria) par 1.
} 
registrar of deeds for the purposes of rescanning. ${ }^{98}$ However, there was no offer to compensate any person who may suffer damages as a result of this loss of information. The question has since been raised as to whether the losses caused by this malfunction of the system may not necessitate some kind of compensation in the form of State or private insurance. ${ }^{99}$ For instance, a township developer may have lodged an application for the development of a new township at the deeds office a few days before the outage over a farm whose title deed had been lost. The application might have been accompanied by an application for a certified copy of the deed in terms of the DRA. ${ }^{100}$ As the deeds office copy had been lost, the owner would not be able to provide his or her copy. Depending on when the title deed was registered and on whether or not the bank enjoyed a security lien as a result of a mortgage bond over the property, the conveyancer who handled the previous transfer may not have the unregistered copy of the title. Therefore, the township may be registered with encumbrances, which may cause financial loss in future. This transaction will fall outside the language of section 99, as there was no mala fide or failure to exercise care on the part of the registrar or any official of the deeds office. Therefore, the loss suffered by the developer will not be compensated under some form of State compensation scheme in terms of section 99. However, such loss, with similar experiences which may occur in any deeds office, may be covered by the provisions of title insurance.

In 2010, an investigation into alleged irregularities revealed 33 properties which were transferred fraudulently by senior officials of the Pretoria deeds office. ${ }^{101}$ The investigation revealed that this corrupt act was perpetrated by these officials, in collaboration with the relevant conveyancer who was instructed to facilitate the transfers. The acts of the officials were arguably mala fide and provided evidence of lack of care and due diligence in the performance of their duties within the confines of section 99 of the DRA. Although no evidence of ever claiming compensation under this section is available, one important challenge may prevent such a claim. This is the fact that the officials were suspended for purposes of conducting further investigations and disciplinary processes. ${ }^{102}$ If they choose to resign, the section does not specifically impose the liability beyond their employment as officials of the deeds office. Furthermore, even if the owner possibly succeeds in reclaiming and retransferring the properties back to him, he will incur further loss which will not be compensated by the State. However, this loss could be indemnified under title insurance.

98 Registrar's Circular 1 of 2008 (Pretoria) par 2.

99 Badenhorst "From Waurn Ponds: Registration of Title or Title by Registration?" 20094 Journal of South African Law 793800.

100 This application is permitted, in terms of Regulation 68(1) of the DRA Regulations, to obtain a copy of the registered copy of title when the registered copy is destroyed or lost in circumstances unknown to the owner.

101 Cokayne "Probe into Fraudulent Transfer of Properties Established" IOL Mobile (2010-0516) http://m.iol.co.za/article/view/s/9/a/7079 (accessed 2013-09-16).

102 IOL Property "Deeds Office Suspends Officials over Property Transfer Fraud" http://www.iolproperty.co.za/roller/news/entry/deeds_office_takes_action (accessed 2014 04-01). 
Two important Supreme Court of Appeal (SCA) decisions and their discussion of the impact of South Africa's negative deeds-registration system are relevant to the introduction of title insurance in South Africa. Both cases relate to claims for the retransfer of registered properties to the rightful owners and the cancellation of registered mortgage bonds over them. Both these claims have adverse financial impacts on both owners and lenders. In the case of Bester NNO v Schmidt Bou Ontwikkelings CC, ${ }^{103}$ the parties agreed that the owner's property would be subdivided into two portions, and to transfer, through sale, a portion to the transferor. The deed of sale, which was entered into before the subdivision was finalized, mistakenly disclosed the whole property as the subject of sale. ${ }^{104}$ The subdivision was approved and the whole property was transferred to the buyer (one Innova Holding (Pty) Ltd). When the seller (Schmidt Bou Onwikkellings CC) became aware of the mistake, it requested co-operation from the buyer to rectify the error, but without success. ${ }^{105}$ The seller then applied to the High Court for, among others, a declaratory order that it is the owner of the whole land mistakenly transferred to the buyer, an order to the Registrar of Deeds to rectify the deed of transfer to reflect this position, and cancellation of the bonds over the property. ${ }^{106}$ When the application was granted in the High Court, the buyer and the mortgagee bank appealed to the SCA. The argument for the declaratory order was centred on whether or not ownership passed from the seller to the buyer. The parties agreed that the transfer of the whole property was a mistake. The court referred to case law which approves the abstract theory of ownership, and concluded that ownership never passed to the buyer, as there was no intention to transfer the whole property. The court, in rejecting the argument that the buyer became the owner, implicitly reached its decision, taking into account the effect of a negative system of registration. It held that "absent any real agreement, [the buyer] as a matter of law, never became the owner of the Remainder, despite the entry in the deeds registry". ${ }^{107}$ The court thus relied on the intention of the parties and questioned the integrity and guarantee of ownership provided by the deedsregistration system. The court implied fraud on the part of the buyer. It concluded that the buyer "opportunistically exploited the mistaken transfer of the property to the advantage of Innova". ${ }^{108}$ This finding of the existence of fraud on the part of the buyer would impact negatively on the buyer when attempting to claim under the title insurance. As already indicated, public policy would undoubtedly not allow the buyer to claim under the insurance when he or she had acted fraudulently to his or her benefit in relation to the acquisition of the property. Title insurance would therefore not cover any loss of property by the buyer in this case.

The court also ordered the cancellation of the bond. The mortgagee's bank, as a result, lost the financial security advanced through the bond.

\footnotetext{
103 Bester NO v Schmidt Bou Ontwikkelings CC supra par 2.

104 Par 3.

105 Par 6.

106 Ibid.

107 Par 11. Authors' own emphasis added.

108 Par 6.
} 
Without any beneficial relief for bondholders in similar circumstances, the loss warrants the taking out of title insurance to cover loss arising from any possible mistake in relation to transfer and ownership of the property. As in this case, the buyer applied for a mortgage over the whole property. As the transfer documents disclosed the whole property, the mortgagee cannot be expected to have knowledge of anything sinister in relation to the documents. In addition, it cannot resort to section 99, as there was no mala fide on the part of deeds registry officials. Therefore, only title insurance may be used to indemnify the owner or the lender against loss caused by the adverse decision relating to this mistake.

In another recent case of Nedbank Limited $v$ Mendelow NO, ${ }^{109}$ the executors of the estate of the deceased (Mrs V) applied to the High Court for an order setting aside a transfer of property by the deceased's children and the cancellation of a bond over the property. The executors alleged that one of the beneficiaries forged the deceased's signature on the contract of sale, which was entered into a week before the death of the deceased. The forged documents were used to apply for the relevant authorization of sale of properties from the deceased's estate by the Master of the High Court and for the subsequent registration of the transfer of property by the deedsregistry office. ${ }^{10}$ The High Court did not dispute the allegation of fraud in relation to the signature. It ordered the property to be returned to the deceased's estate and for the bond registered over it to be cancelled. ${ }^{111}$ For reasons that are not relevant to this discussion, the mortgagee appealed the order for the cancellation of the bond. ${ }^{1}$

The SCA acknowledged the undisputed fraudulent act by the deceased's son. ${ }^{113}$ It analysed the effect of fraud on the passing of ownership under our deeds registration system. The court reiterated the debate regarding the South African land registration system as a negative system which does not guarantee the title that appears in it. ${ }^{114}$ The court held further that a transfer which is carried out as a result of forged documents creates no rights at all, as there is no guarantee of title from the registration. ${ }^{115}$ The court concluded that as there was no intention on the part of the deceased to transfer ownership, such ownership did not pass to the buyer. ${ }^{116}$ Consequently, the bond registered over the property by the buyer was also not valid. It ordered the reregistration of the property in the name of the estate of the deceased, and allowed a claim by the executors for the cancellation of the registered bond over the property.

The court's decision had financial implications for both the buyer and the mortgagee. There was no evidence that the buyer knew about the fraudulent transfer by the deceased's son, or acted fraudulently in relation to such

\footnotetext{
109 Nedbank Limited v Mendelow NO (686/12) [2013] ZASCA 98(5 September 2013).

110 Par 4.

111 Par 7.

112 Par 10.

113 Par 11.

114 Par 12.

115 Par 12

116 Par 15.
} 
transfer. There was also no indication that the deeds registry officials acted with no care and diligence or with mala fide, as provided in section 99. The court referred to the duty of the Registrar of Deeds as "clerical acts". ${ }^{117}$ Because of the negative system of registration, the deeds office could not be held liable in the absence of any mala fide. Arguably, only title insurance could indemnify the buyer against loss suffered as a result of a vindicatory action for retransfer of the property to the owner. Likewise, it would cover indemnification of the money advanced to the buyer by the mortgagee in relation to the mortgage bond over the property.

\section{CONCLUSION}

The South African deeds registration system has attempted to provide a guarantee of rights through the recording of title and examination of the validity of transactions by the officials of the deeds office. Where these officials act with dishonesty or below the standard of care required by the DRA, the State or individual official may be held personally responsible for any loss suffered as a result of any defect in the title. Ownership of property in South Africa is based on an abstract system which puts the emphasis on the intention of the parties to transfer and receive ownership. However, it becomes a challenge for the registration of land to rely on the intention of the parties, which might not be evident from the registered documents. Therefore, no guarantee of title can be ensured and any possible loss or adverse claim relating to registered rights may not be avoided. In addition, the provision of section 99 cannot be compared with State compensation under the Torrens system in other countries where the State has compensatory funds. The stringent provisions of this section are aimed at excluding the State from liability, rather than providing indemnity in case of loss. The evidentiary circumstances discussed above are just the tip of the iceberg in relation to some of the potential defects of the deeds registry system in South Africa. For instance, the introduction of the electronic registration system should be a red flag for titleholders and lenders of the possible losses that may be suffered if something goes wrong or if the system is abused. Bondholders will continue to suffer huge financial losses, as the negative deeds-registration system does not provide any guarantee that once a deed of transfer is registered, the owner is in fact the legal owner of the property, as recorded in the deeds registry. As the Bester ${ }^{118}$ and Mendelow $\mathrm{NO}^{199}$ cases have illustrated, purchasers of land can expect their ownership to be disputed, with little protection from the land registration system. Likewise, financial institutions that advance payments towards buyers for purchasing these properties should not expect any protection from the registration system if the ownership of these properties is the subject of disputed rights. The answer, however, does not depend on whether or not South Africa should supplement its negative registration system with some elements of the positive system, such as a State

17 Par 24.

118 Bester NO v Schmidt Bou Ontwikkelings CC supra.

119 Nedbank Limited v Mendelow NO supra. 
TITLE INSURANCE IN THE SA PROPERTY-REGISTRATION SYSTEM 111

compensation scheme. The answer depends, it is submitted, on creating a legal framework for the introduction of title insurance. As insurance is based on a contract between the insurer and the insured, the extent of the risks covered will be determined by the insurance industry and the particular contract. This will overcome the limited protection of the deeds registration system, as well as the limited compensatory mechanism provided under section 99 of the DRA. It is submitted that once title insurance is introduced, the legal framework will provide adequate regulation of some of the issues, such as double indemnity or whether or not it should extend to other risks such as litigation costs. 